\title{
Spirit is Collaborative
}

\author{
Charlotte Henay \\ York University \\ chenay@yorku.ca
}

I am interested in only telling certain parts, untelling certain parts, keeping the bodies and the parts from becoming a settlement. I keep a list of theories of change in my pocket so I can remember something more meaningful than raising awareness. Something more material than raising consciousness. Something more to the touch than visibility. My list of theories of change: haunting, visitations, Maroon societies, decolonization, revenge, mattering.

- Morrill, Tuck, \& SFHQ

I want a woman to oil and bind my hair

In the place where your fingers turn blue

to subliminally converse with grace

paying attention to tucking the ends in tight

enough so they don't come undone in the night

loose enough so my head doesn't hurt

what becomes of the world when she is not there for you

does not come when you call

cannot be recognized by her nighttime knocking

grammie opens the ground for spider

birdsong bespoke multiverse Oyá carried the wind

$* * *$

sugar plum fairies rat-a-tat-tat

bullets and magic go just like that

my tongue cloven I see what you do

can' tell what I know but I know it's true

cry baby cry ya mummy ain' comin' for you

$* * *$

Intestate

Inchoate

Indecipherable

Incommensurate

we never get right inside the shell the masquerade

it's amazing how quickly one can be poisoned from the insight out

not knowing

in other jurisdictions the trees bleed their lives

into plates in a sacred dialysis over seas

this year's key master woos foreigners for hidden money ${ }^{\mathrm{i}}$

$* * *$

Cultural and Pedagogical Inquiry, Fall 2018, 10(2), pp. 178-181

ISSN 1916-3460 @ 2018 University of Alberta

http://ejournals.library.ualberta.ca/index.php/cpi/index 
$m u d d o^{\mathrm{ii}}$ emblazoned across my centre because your mouth was foul and it is almost dirty and easy yet still incomplete I've come to understand that these idead these talks they are for the moments of inbetween time space and place the ones that were so vibrant and all-consuming explosive love bound the very few breaths times fingertip brushes where you were fiercely my mother more than someone else's daughter far away sister bound

these talks they are for revelatory instances of why the breaths were so very few what brought us to these oceans apart again again again is the only reason I am learning to bend time so that I can tell this all to you without stone dirt sand as translator

$* * *$

I brought you home against your wishes either way you were going to be buried amongst white folks who didn't recognize you

$* * *$

How do you see bringing back vision to our people our people our people our our return of one hundred and ninety six slaves the property of the Estate of late of the Island of New Providence deceased on the thirty first day of July 1834 name sex colour condition free slave ditto ditto also do free do slave do do do do whether African or Creole how disposed of suky pender sue fatima field labourer on plantation Rum Key alexander will billy how are they employed since or if acquired since that date how and where employed since the time of acquisition elizabeth tia return time date time schedule of the Slave Population of the slaves who have ranaway or absconded from the said Islands, of the Slaves who have died and of the slaves who have been Manumitted between and pursuant to An Act of the General Assembly in such case made and provided reparations knowledge about our people as reparations

$* * *$

microfiche runs this script across my eyeballs behind lids squeezed tight backlit like old negatives reading the dead nights like this I can smell the ocean from inside it's so little she has let me make her dinner I feel benevolent and less lonely she gets food and this is how she loves me

acquiescent I ride chains and banana boats home

I think of wine in the mornings this

is the first time in forty years I've seen a silk cotton flower

an almond tree lose its leaves

how is it going she says except it's really como te ha ido amiga

I hear Anita

my mother's eldest sister dead at twelve from typhoid in the water after the 1928 hurricane

I'm breaking I want to say

this isn't new

therefore doesn't bear repeating

I tell her I'm shapeshifting

all these come after I have always been homeless though unaware until she left me

Cultural and Pedagogical Inquiry, Fall 2018, 10(2), pp. 178-181

ISSN 1916-3460 @ 2018 University of Alberta

http://ejournals.library.ualberta.ca/index.php/cpi/index 
I know if I say this she will disappear for a while leave me alone in bed

in the middle of the hot sunny afternoon

I won't have to explain being split open from the inside out

while dreaming

of getting up to walk mummy's old yard

or the call that never comes from that auntie that cousin that old friend who

wants to show you where your childhood home stands now

behind neon flavored advertisements

has no criticism to offer

is not hiding

does not call you adjectives in a string

remembers her own days of deep unrelenting sorrow that lived upstairs from Grammie

not in the house that is now a liquor store on a thoroughfare

a persona it inherited from long ago inhabitants and their familiars

what do these superwomen embracing the designation think as I story blindigeneity is it a silent recognition those deluded colored folks sure didn't know what to do with this one see now she burns down her own house madness runs rampant amongst her people our people know how we got here and what happened in between stories that bind us

$* * *$

Spirit is collaborative. My mother understood how that works. In talking about what I think of as collective memory and memorialization, she said, "you know, when you have memories and sometimes you want someone else to have them too, then you repeat the same story over and over again." What she didn't talk about, because we don't, is what remains unsaid - and how that, too, is a form of collaborative memorying. There is no other way to come at it than from the outside in.

My interest is in how we rememory together, at the interstices of public history and experimental writing ${ }^{\text {iii }}$. We claim space in poetry as a radical act, sitting in an examination of grief as catalytic amidst "unspeakable things unspoken"iv. When we memory together we create a language potentially transformative of mourning, death, pain as solitary and paralyzing, to an articulation for writing ourselves into the future. One of the means to this end is making the "unseen, visible", telling our own stories, bringing black and indigenous womxn's voices to the forefront. The words we use and how we use them become self-fulfilling prophecy, and determinative in the context of futurities, we speak into becoming.

I don't often make rhymes except for when the avarice of sitting with the bones brings nausea insomnia she says one full round of seasons to become proficient in talking to the dead.

All literature is politics is shaped by the weight of our pasts ${ }^{\mathrm{vi}}$ deliberately reclaiming our ancestors stories refusing to teach our children to endure we break the frame ${ }^{\text {vii }}$ continue to reimagine ourselves write against a monolithic dictation of being there is no return my heart sinks the bottom is a portal to our dead and each other magic is relationship if it isn't mutual it isn't emancipatory is negotiated at the interstices is subversive is an anthology a space for healing a diversionary transformative justice project is a poem

$* * *$

Cultural and Pedagogical Inquiry, Fall 2018, 10(2), pp. 178-181

ISSN 1916-3460 @ 2018 University of Alberta

http://ejournals.library.ualberta.ca/index.php/cpi/index 
when you ask for all the blocks to be removed remember

those are also to the chambers of your own heart

for which comes first

someone else's memory of the liquor store house or the nausea that is mine

alone

exploited and marketed movement across water makes me nervous

ambidextrous in life both sides of the road both sides of the spirit

how is one specific in this context

I think oh god please don't let me fall through

\section{Endnotes:}

${ }^{\mathrm{i}}$ On March 13, 2018, The Bahamas is blacklisted by the EU as non-cooperative http://www.tribune242.com/news/2018/mar/13/bahamas-blacklisted-european-union/

ii https://www.urbandictionary.com/define.php?term=muddo

iii Marriott, D. (2017). Introduction: Black Experimental Poetics. The Black Scholar, 47(1): 1-2. http://doi.org/10.1080/00064246.2017.1264826

${ }^{\text {iv }}$ Morrison, T. (1988). Beloved. New York, NY: Penguin Books.

v Bunch, L. (2017, March 24). Day of Remembrance 'A Clarion Call to Remember', Keynote Speaker Tells General Assembly Tribute for Victims of Transatlantic Slave Trade. Retrieved from: https://www.un.org/press/en/2017/ga11900.doc.htm

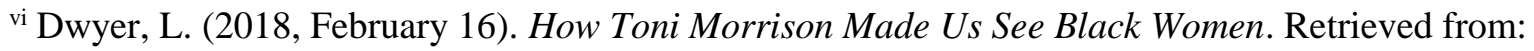
https://www.shondaland.com/inspire/books/a18203931/toni-morrison-birthday/

vii Civil, G. (2017). Swallow the fish. 2017. Fairfax, VA: Civil Coping Mechanisms Press. 